\title{
A review of the effects of supplementary nutrition in the ewe on the concentrations of reproductive and metabolic hormones and the mechanisms that regulate folliculogenesis and ovulation rate
}

\author{
Rex J. ScARAMUZZI ${ }^{\mathrm{a} *}$, Bruce K. CAMPBELL ${ }^{\mathrm{b}}$, Jeff A. DownING ${ }^{\mathrm{c}}$, \\ Nigel R. KENDALL ${ }^{\mathrm{b}}$, Muhammad KHALID ${ }^{\mathrm{a}}$, \\ Minerva MUÑOZ-GUTIÉRREZ ${ }^{\mathrm{d}}$, Anongnart SOMCHIT ${ }^{\mathrm{a}}$ \\ ${ }^{a}$ Department of Veterinary Basic Sciences, Royal Veterinary College, Hawkshead Lane, North Mimms, \\ Hertfordshire, AL9 7TA, UK \\ ${ }^{\mathrm{b}}$ Division of Obstetrics and Gynaecology, School of Human Development, University of Nottingham, \\ Queens Medical Centre, Nottingham NG7 2UH, UK \\ ${ }^{c}$ Department of Animal Science, University of Sydney, Camden, 2570, NSW, Australia \\ d Departamento de Biología de la Reproducción, Universidad Autónoma Metropolitana Iztapalapa,
} 09340 Mexico City, Mexico

\begin{abstract}
This paper discusses the phenomenon of nutritional flushing in ewes whereby increased nutrition stimulates folliculogenesis and ovulation rate. In addition the paper reviews recent findings on the effects of increased levels of nutrition on the blood concentrations of reproductive and metabolic hormones in the ewe and some of the intraovarian changes that take place in response to nutritional stimulation. Finally, in the paper, we propose a model of the physiological mechanism for the nutritional stimulation of folliculogenesis and we review how closely the model fits recent published and unpublished evidence examining the mechanism of flushing. Nutritional stimulation alters the blood concentrations of some metabolic hormones. By using short-term models of nutritional flushing, we have shown that as the blood concentrations of insulin and leptin increase that of growth hormone decreases while that of IGF-I appears unaffected by the nutritional flushing. Nutritional flushing also alters the blood concentrations of some reproductive hormones. Again, using the same model, we have shown that there is a transient increase in FSH and a decrease in oestradiol concentrations in the blood. The changes in oestradiol are particularly evident in the follicular phase of the oestrous cycle. In the ovary, the effect of nutrition is to stimulate folliculogenesis. These changes are associated with intra-follicular alterations in the insulin-glucose, IGF and leptin metabolic systems. The stimulation of these intra-follicular systems leads to a suppression in follicular oestradiol production. The consequence of these direct actions on the follicle is a reduced negative feedback to the hypothalamic-pituitary system and increased FSH secretion that leads to a stimulation of folliculogenesis.
\end{abstract}

insulin / leptin / IGF-I / glucose / FSH / oestradiol

\section{INTRODUCTION}

The effects of nutrition on reproduction are well known and widely reported. They

\footnotetext{
* Corresponding author: rscara@rvc.ac.uk
}

occur not only in the ruminant species $[1,2]$ but in monogastric species as well [3-6]. Nutrition affects all aspects of the chain of reproductive events from gametogenesis to puberty in both males and females. The 
reason for this close association between nutrition and reproduction is to ensure that reproduction is very closely aligned with the food supply. Such an alignment is essential to ensure the success of reproduction by timing lactation and neonatal growth, both of which are intense, energy demanding processes, to the expected availability of a high quality food supply. If this timing is mis-matched then the life of the offspring and in extreme cases that of the mother herself, is endangered.

Although the close interdependence of seasonal nutrition with reproduction is a critical factor for the survival of a species in its natural environment, with domestication this alignment becomes a major source of production inefficiency. Thus, sheep and goats have powerful physiological mechanisms that limit reproduction to the autumn months and births to seasons that are favourable to survival. However, in commercial production systems these may not always be the most suitable times for farmers to breed their flocks.

The female energetic investment in reproduction is considerable and the consequences of a mistake are serious and life threatening to both the mother and offspring. The male is very different, the nutritional investment in reproduction is less than that of the female and although the consequences of a mistake may have a high genetic cost through producing fewer offspring, they are not life threatening to either himself or his offspring. In the case of the ram, the reproductive system responds to nutritional signals by adjusting sperm production to match the nutritional conditions. For the ewe, the reproductive outcome in response to nutritional signals is more complex. The first reproductive response to nutritional input is whether to reproduce or not; if this decision is to reproduce the reproductive system has to then set the level of reproduction to one or two lambs. Since the biological effects and consequences of nutrition on male and female reproduction are very different, it seems very likely that the mechanisms that link these two physiological systems will also be different.

In sheep, follicle populations are very sensitive to nutritional input and folliculogenesis and ovulation rate can be readily increased by nutritional manipulation. The manipulation of reproduction using nutrition is an inexpensive management tool to control ovulation rate and litter size particularly in low cost, extensive production systems in marginal environments such as the semi-arid, Mediterranean and hill farming regions of the world [7]. A clearer understanding of these associations at a mechanistic level is needed if we are to fully exploit the potential of nutritionally manipulated reproduction. This paper will describe some of the more recent insights from our research, into these mechanisms.

\section{WHAT IS THE RELATIONSHIP BETWEEN NUTRITION AND REPRODUCTION?}

One way of viewing the relationship between nutrition and reproduction is through energy balance. When the animals' net nutrient requirement is more than the net nutrient intake the animals will use their energy stores (glycogen, triglycerides and protein) to meet the deficit. When an animal is in this state, it is in "negative energy balance". Similarly, when the net nutrient requirement is less than the net nutrient intake, the animal will store the excess nutrients (as glycogen and triglycerides) and/or disperse the excess nutrients as metabolic heat. When an animal is in this state it is in "positive energy balance". These metabolic states and the accompanying alterations in appetite and nutrient partitioning within the body are regulated by a series of complex interactions among the blood concentrations of metabolic hormones and various 
Table I. Some known associations between energy balance and reproduction.

\begin{tabular}{|c|c|c|}
\hline Metabolic state & Metabolic consequences & Effects on reproduction \\
\hline Negative energy balance & $\begin{array}{l}\text { - Weight loss } \\
\text { - Fat stores depleted } \\
\text { - Muscle wasting } \\
\text { - Hypoinsulinemia } \\
\text { - Hypoglycaemia } \\
\text { - Elevated } \beta O H \text { butyrates } \\
\text { and NEFA } \\
\text { - Elevated GH } \\
\text { - Low Leptin } \\
\text { - Reduced metabolic heat } \\
\text { - Suppressed IGF system } \\
\text { - Elevated urea }\end{array}$ & $\begin{array}{l}\text { - Inhibition of GnRH secretion by the } \\
\text { hypothalamus } \\
\text { - Absence of LH pulses } \\
\text { - Low FSH concentrations } \\
\text { - Inhibition of folliculogenesis } \\
\text { - Low oestradiol } \\
\text { - High negative feedback sensitivity } \\
\text { - Anovulation } \\
\text { - Anoestrus } \\
\text { - Delayed puberty }\end{array}$ \\
\hline Energy balance & $\begin{array}{l}\text { - Weight maintained } \\
\text { - Fat stores maintained } \\
\text { - Normal insulin } \\
\text { - Normoglycaemia } \\
\text { - Low NEFA and } \beta \mathrm{OH} \text { butyrate } \\
\text { - Normal GH } \\
\text { - Normal Leptin } \\
\text { - Normal IGF system } \\
\text { - Normal urea }\end{array}$ & $\begin{array}{l}\text { - Normal GnRH secretion by the } \\
\text { hypothalamus } \\
\text { - Normal LH pulsatility } \\
\text { - Normal FSH concentrations } \\
\text { - Normal folliculogenesis } \\
\text { - Normal oestradiol and inhibin } \\
\text { - Normal negative feedback } \\
\text { - Ovulation } \\
\text { - Oestrus } \\
\text { - Ovulation rate below natural } \\
\text { maximum }\end{array}$ \\
\hline Positive energy balance & $\begin{array}{l}\text { - Long-term weight gain } \\
\text { - Fat stores increased } \\
\text { - Hyperinsulinemia } \\
\text { - Hyperglycaemia } \\
\text { - Low NEFA and } \beta \mathrm{OH} \text { butyrate } \\
\text { - Low GH } \\
\text { - Elevated leptin } \\
\text { - Increased metabolic heat } \\
\text { - Stimulated IGF system } \\
\text { - Urea normal but can be high if } \\
\text { dietary nitrogen is high }\end{array}$ & $\begin{array}{l}\text { - Normal GnRH secretion by the } \\
\text { hypothalamus } \\
\text { - Normal LH pulsatility } \\
\text { - Increased FSH concentrations } \\
\text { - Enhanced folliculogenesis } \\
\text { - Reduced oestradiol } \\
\text { - Reduced negative feedback } \\
\text { - Ovulation } \\
\text { - Oestrus } \\
\text { - Maximum natural ovulation rate } \\
\text { - Advanced puberty }\end{array}$ \\
\hline
\end{tabular}

whole-body nutrient fluxes. Many of the metabolic hormones and nutrients that help to maintain whole-body nutrient homeostasis also affect the reproductive system. Consequently, there are well-defined associations between metabolic state and reproduction (Tab. I).
The effects of negative energy balance on reproduction are primarily at the hypothalamo-pituitary level of reproductive control [8] and are characterised by hypoglycaemia, hypoinsulinaemia, suppressed plasma IGF-I and elevated plasma $\mathrm{GH}$, changes that are associated with the 


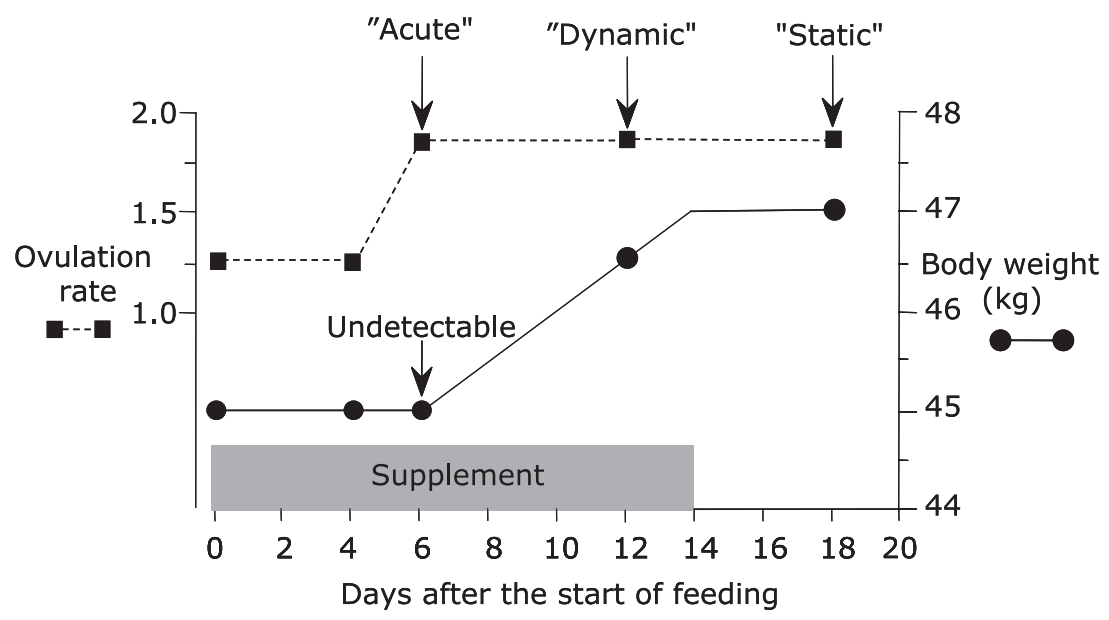

Figure 1. The "acute", "dynamic" and "static" influences of nutrition on ovulation rate in sheep. See text for further details.

inhibition of GnRH pulsatility, anovulation and anoestrus in the female. There is little evidence to suggest that negative energy balance has any direct ovarian effects in the ewe that are independent of its effects on the hypothalamo-pituitary axis $[9,10]$. However, in the lactating dairy cow there is strong evidence to suggest that negative energy balance has some direct inhibitory effects on folliculogenesis and oocyte quality $[11,12]$.

Positive energy balance leads to increased leptin and insulin concentrations in the blood and increased glucose uptake; these changes appear to affect the ovary directly and are associated with increased folliculogenesis and increased ovulation rate in sheep. Positive energy balance is also associated with alterations in the hepatic metabolism of steroids [13, 14] that can lead to disturbances in negative feedback between the ovary and the hypothalamo-pituitary system and theoretically, to increased folliculogenesis. There is little evidence to suggest that positive energy balance has a specific stimulatory action on the hypothalamo-pituitary axis [8]. It is worth noting that because of the strong negative feedback interrelationship between the hypothalamo-pituitary axis and the ovary, the task of identifying the anatomical sites in the reproductive axis that are influenced by nutrition is proving to be exceedingly difficult.

Positive energy balance, if it persists, will inevitably increase body weight. However, the stimulatory effect of nutrition on folliculogenesis can occur before there is any detectable increase in body weight. The careful descriptive analysis of the effects of nutrition on body weight has led to a classification of nutritional effects on ovulation rate (Fig. 1). The "acute" effect is seen in the absence of a detectable change in body weight, the "dynamic" effect is associated with increasing body weight and the "static" effect is associated with elevated body weight per se. A frequently posed question is if these three patterns of reproductive response to nutrition are mediated by a single mechanism or by multiple mechanisms. At this time we can only speculate about the answer.

Whatever the nature of these mechanisms, the links between the metabolicnutritional system and the reproductive 
system almost certainly involves one or more of the metabolic hormones and nutrient fluxes that are an integral part of nutrient utilisation and whole body nutrient homeostasis. Many of the hormonal systems that respond to nutrition also affect the ovary and it is from among these that several research teams around the world are seeking to unravel the mechanisms that link nutrition and the follicle. Strong contenders among many for the "link" between nutrition and the follicle are the glucose-insulin system, IGF system and leptin system.

The nutrient requirements for folliculogenesis are not known but they are unlikely to be significant in terms of whole body energy utilisation. However, the nutrient requirement for other reproductive events such as foetal growth, lactation and pubertal growth are all very high and significant in the context of whole body energy utilisation. In these later states the effect of nutrition on reproduction is a question of nutrient supply, particularly energy. In these reproductive states, failure to meet the nutrient demand will compromise reproduction. The mechanisms of nutritional effects on folliculogenesis are probably not effects of quantitative nutrient supply per se; it is much more likely that they are specific nutrient signalling effects that link reproduction with favourable environmental conditions for reproduction. For spermatogenesis and folliculogenesis, nutrition acts as a metabolic signalling mechanism.

\section{ANIMAL MODELS}

Until the seventies, experiments examining the relationship between nutrition and reproduction in sheep were descriptive in nature and generally used litter size as an end point. The static and dynamic effects of nutrition on reproduction were analysed empirically in great descriptive detail without any significant advance in our knowledge of the underlying mechanisms. The seventies saw a number of important developments: first, the introduction of laparoscopy [15] that allowed the measurement of ovulation rate rather than litter size, second, the development of radioimmunoassays for the measurement of the blood concentrations of LH, FSH, progesterone and oestradiol and finally, the discovery of the acute effect of nutrition on ovulation rate [16]. Since then numerous mechanistic studies have improved our understanding of the physiological processes involved and now we are able to propose coherent testable hypotheses to explain how nutrition increases ovulation rate in sheep [17-19]. In our research we used the "acute" effect in preference to the "static" or "dynamic" effects as our experimental model because the responses to the "acute" effect are reproducible, the experimental designs are simple and not complicated by potential confounding factors and finally, the experiments are much easier to manage. We used two nutritional models: first, feeding a lupin grain supplement and second, the intravenous infusion of glucose. In both models the period of treatment was either 3 or 5 days (Fig. 2).

\section{THE METABOLIC EFFECTS OF NUTRITIONAL SUPPLEMENTS}

\subsection{Insulin and glucose}

Feeding $500 \mathrm{~g}$ of lupins per day as 2 meals of $250 \mathrm{~g}$ each in the morning and evening increased plasma glucose and plasma insulin concentrations in female sheep (Fig. 3). The infusion of glucose at $50 \mathrm{mM} / \mathrm{h}$ also increased plasma concentrations of glucose and insulin [20,21] but the blood levels were very high and outside the normal physiological range for glucose. Glucose infusion led to an immediate increase in insulin concentrations that remained elevated for the duration of the 


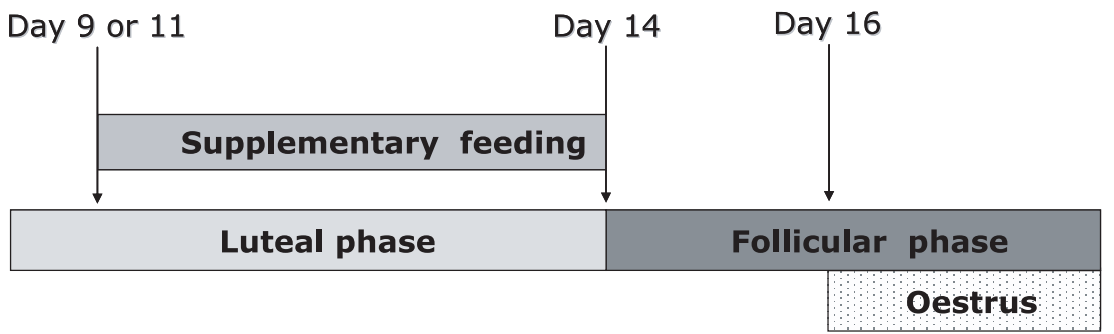

\section{Luteolysis LH surge Ovulation}

Figure 2. The short-term nutritional model. A short-term supplement of $500 \mathrm{~g}$ of lupin grain $(250 \mathrm{~g}$ twice a day) is fed for 3 or 5 days towards the end of the luteal phase of the oestrous cycle and ending at the time of luteolysis.
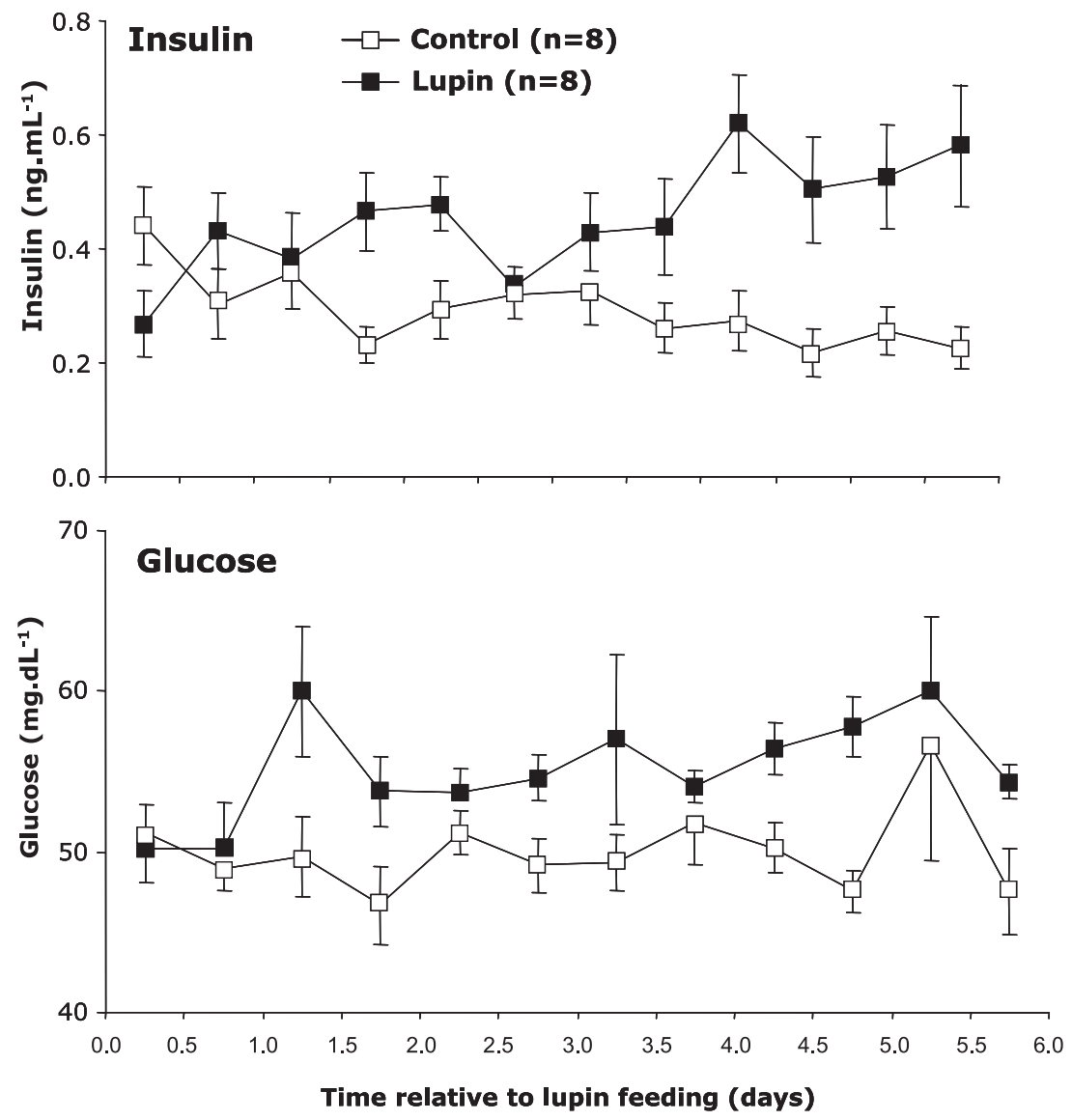

Figure 3. The plasma concentrations of insulin and glucose in sheep fed a lupin grain supplement for 5 days in the late luteal phase of the oestrous cycle (A. Somchit, B.K. Campbell, N.R. Kendall, M. Khalid and R.J. Scaramuzzi; unpublished data). 


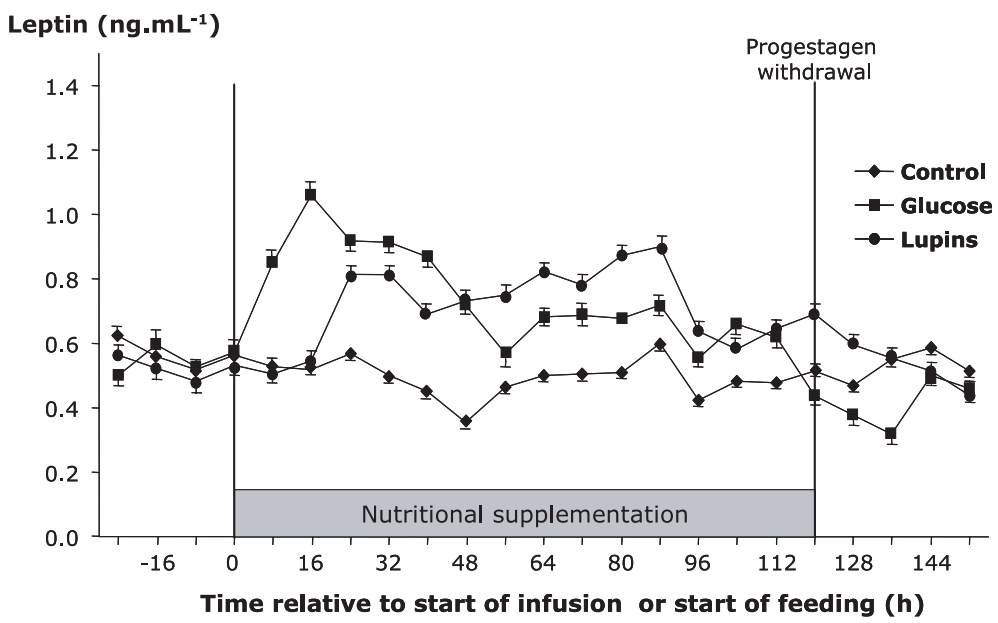

Figure 4. The plasma concentrations of leptin in sheep fed a lupin grain supplement or infused with glucose at $50 \mathrm{mM} \cdot \mathrm{h}^{-1}$ for 5 days in the luteal phase [20].

treatment period $[20,21]$. The time course of insulin concentration was different with lupin feeding: compared to glucose infusion, the increase was slower and more gradual $[20,21]$. These differences probably reflect the way in which the two treatments perturb metabolic homeostasis.

\subsection{Leptin}

Feeding lupins at $500 \mathrm{~g}$ per day as 2 meals of $250 \mathrm{~g}$ each in the morning and evening and the intravenous infusion of glucose both increased plasma leptin concentrations (Fig. 4). Glucose infusion produced an immediate increase in leptin concentrations that remained elevated for the duration of the treatment period. The time course of leptin concentrations was different to that with lupin feeding. The increase was slower and more gradual. These differences probably reflect delays associated with the digestion of lupin grain in the alimentary tract of the ewe. Leptin responds to acute changes in the diet and it also measures long-term reserves of body energy. The greater these reserves, the higher the blood concentration of leptin [22]. Thus the blood concentration of leptin sends signals to the follicle about the short-term effects of nutritional supplements that do not change body weight (i.e. the "acute effect") and the long-term effects of increased body weight (i.e. the "dynamic" and "static" effects).

\subsection{Insulin-like growth factor I (IGF-I)}

Short-term nutritional supplementation with either glucose or lupins had no effect on the plasma concentration of IGF-I (M. Muñoz-Gutiérrez, unpublished data). This was in contrast to other published data that suggests that undernutrition reduces IGF-I concentrations in sheep and dairy cattle $[9,11]$. This difference could be due to a differential effect of nutritional supplementation and under-nutrition on blood IGF-I concentrations. Alternatively, it could be an effect of time and a longer period of nutritional supplementation than that used in our model (5 days) might be required to stimulate IGF-I secretion. Since IGF-I itself does not respond to short-term nutritional supplementation the short-term effects of nutrition on the IGF system in the follicle $[20,23]$ must 
be mediated by some other mechanism. It seems highly likely that this mechanism involves both the insulin-glucose system and the leptin system.

\subsection{Growth hormone (GH)}

The infusion of glucose increased GH concentrations in ewes [21]. However, feeding lupin grain had the opposite effect [24] but both of these treatments stimulated folliculogenesis and increased the ovulation rate in ewes. This inconsistency suggests that nutritional effects on the ovary are independent of diet-induced changes in GH concentrations. Exogenous $\mathrm{GH}$ administered to cattle increases the number of medium-sized follicles but has no effect on ovulation rate [25], and these authors concluded that most of the actions of $\mathrm{GH}$ on the follicle could be accounted for by its action in stimulating hepatic IGF-I secretion [26].

\section{THE EFFECTS OF NUTRITIONAL SUPPLEMENTS ON THE FOLLICLE}

Glucose infused for 3 or 5 days stimulated folliculogenesis by increasing the numbers of large follicles but without any effect on the number of small and mediumsized follicles [20, 21, 23]. Lupin feeding increased the number of large follicles although to a lesser extent than glucose-infusion. The main influence of lupin feeding was on medium-sized follicles the numbers of which were approximately doubled by lupin feeding ([20,27, 28], A. Somchit et al. unpublished data). The infusion of leptin at a systemic dose of $1 \mu \mathrm{g} . \mathrm{h}^{-1}$ increased the number of large follicles $>3.5 \mathrm{~mm}$ but, did not effect the number of medium sized $1-3.5 \mathrm{~mm}$ follicles [29]. These data suggest that the effect of lupin grain supplementation on folliculogenesis is not solely mediated by the glucose-insulin and leptin systems.

\section{INTRA-FOLLICULAR EFFECTS OF NUTRITIONAL SUPPLEMENTS}

Intra-follicular actions of the insulinglucose, IGF and leptin systems have all been unequivocally demonstrated in sheep. Both the infusion of glucose and the feeding of a lupin grain supplement affect all of these intra-follicular systems [20,23]. There are effects of short-term nutritional treatments on the intra-follicular insulinglucose system, IGF system and leptin system and it is clear that components of all three of these metabolic systems are nutritionally regulated in the follicle. The effects of both these treatments, while broadly similar, are not identical. These are summarised in Table II.

\subsection{The insulin-glucose system}

The intra-follicular insulin-glucose system is stimulated by nutritional treatments. There is increased expression of GLUT-1 and GLUT-4 proteins in granulosa and theca cells [30] and glucose uptake by the ovary [31]. The effect of nutritional treatments such as glucose infusion or lupin feeding, on the expression of GLUT in the ovary is not clear [30] but lupin grain supplements increase glucose entry rate in the ewes [32]. The reproductive effects of either infusing glucose or of feeding lupins are to suppress follicular phase oestradiol secretion (Fig. 5) and to stimulate folliculogenesis and increase the ovulation rate.

\subsection{The leptin system}

The leptin system is present in the follicle. The mRNA for both the full length signalling form of the leptin receptor $(\mathrm{ObRb})$ 

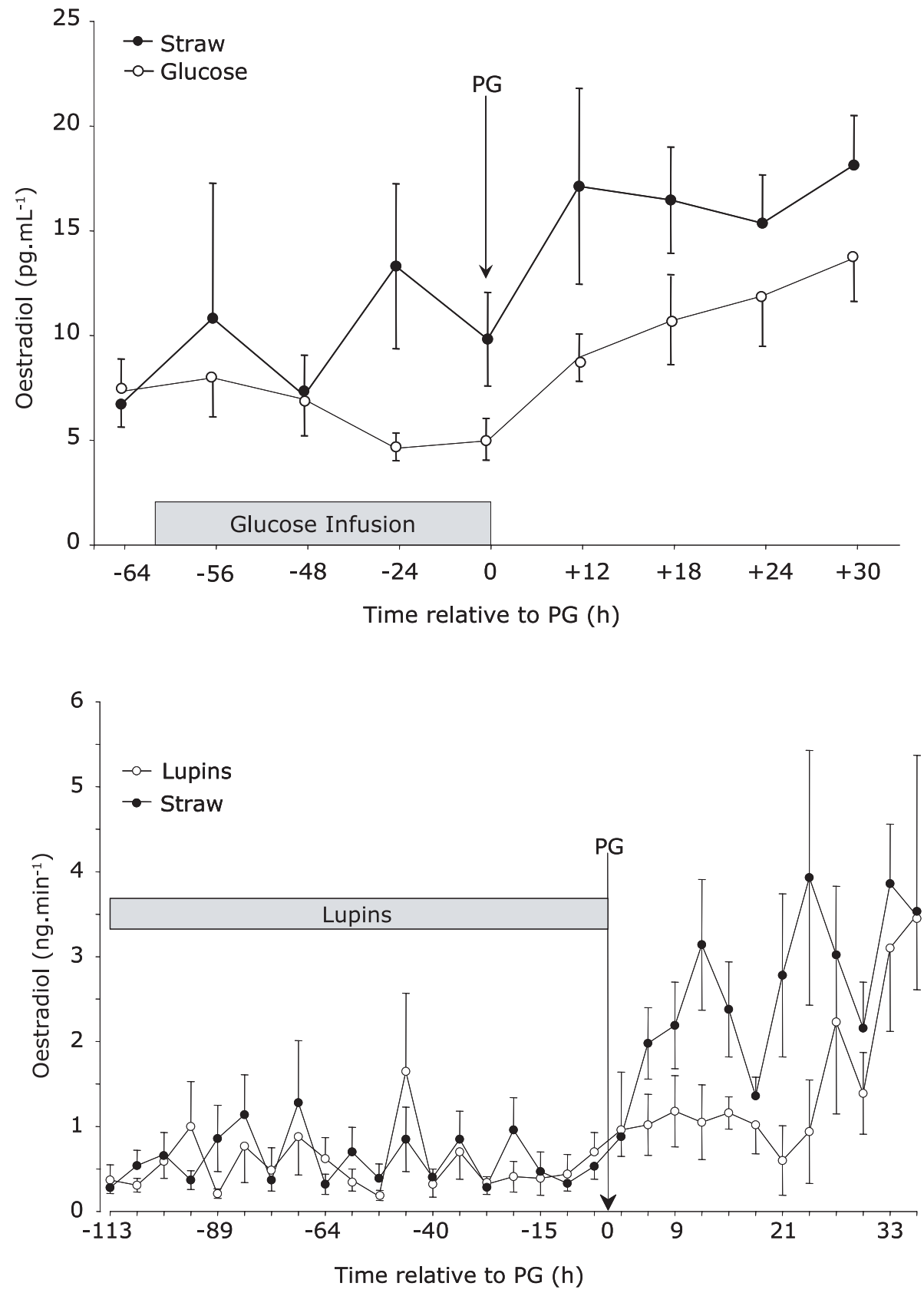

Figure 5. The plasma concentration of oestradiol in the late luteal and follicular phases of the oestrous cycle in ewes infused with glucose (top) or fed lupins (bottom) during the late luteal phase (glucose: [23], lupins: J.A. Downing and R.J. Scaramuzzi; unpublished data). 
Table II. A summary comparison of the intra-follicular and systemic effects of short-term treatments with glucose infused intravenously for up to 5 days and feeding lupin grain as a dietary supplement for up to 5 days. (Information in the table is from several sources [20,24, 28, 31,32,45], Somchit et al., 2006 unpublished data; Kendall et al., 2006 unpublished data.)

\begin{tabular}{llll}
\hline & & Intravenous glucose & Feeding lupins \\
\hline \multirow{2}{*}{ Follicle number } & Total & Unchanged & Increased \\
& Small $(<3.5 \mathrm{~mm})$ & Unchanged & Increased \\
Ovulation rate & Large $(>3.5 \mathrm{~mm})$ & Increased & Increased \\
Oestradiol secretion & Increased & Increased \\
Inhibin secretion & Decreased & Decreased \\
FSH concentrations & Unknown & Unknown \\
Insulin & Transiently increased & Transiently increased \\
IGF-I & Increased & Increased \\
Leptin & Unchanged & Unchanged \\
Growth hormone & Increased & Increased \\
Intra-follicular & Decreased & Decreased \\
insulin-glucose system & Stimulated & Stimulated \\
& - Glucose uptake increased & - Glucose uptake increased \\
& & - Glucose elevated in \\
Intra-follicular IGF system & & follicular fluid \\
& Suppressed action of IGF-I & Suppressed action of IGF-I \\
& - Decreased IGF-IR mRNA & - Decreased IGF-IR mRNA \\
& - Increased IGFBP2 mRNA & - Increased IGFBP2 mRNA \\
Intra-follicular Leptin system & - Decreased IGFBP5 mRNA & - Decreased IGFBP5 mRNA \\
& Stimulated & Stimulated \\
& - Increased leptin mRNA & - Increased leptin mRNA \\
& - Increased ObRb mRNA & - Increased ObRb mRNA \\
\hline
\end{tabular}

and leptin itself are present in sheep follicles $[23,28]$. The infusion of glucose and the feeding of a lupin grain supplement both increased the number of follicles with mRNA for ObRb. In a series of experiments we examined the effects of leptin on the follicle $[28,29]$. In summary, these experiments revealed that leptin inhibits the in vivo secretion of oestradiol and stimulates folliculogenesis during the follicular phase of the oestrous cycle and furthermore that passive immunisation against leptin has the opposite effect of increasing the in vivo follicular secretion of oestradiol during the follicular phase [29]. The inhibitory effect of leptin on follicular oestra- diol secretion was seen only at low doses $\left(2 \mu \mathrm{g} . \mathrm{h}^{-1}\right)$ and not at high doses $\left(20 \mu \mathrm{g} . \mathrm{h}^{-1}\right)$ of leptin [29].

\subsection{The IGF system}

IGF-I is an extremely potent stimulator of follicular proliferation and follicular steroid secretion in most species. Experiments with the sheep ovarian autotransplant model have shown that the IGF-LR3 analogue (that does not bind to IGF binding proteins) has short-term stimulatory effects on follicular steroidogenesis [33] and long-term stimulatory effects on follicular 
proliferation that lead to hypersecretion of oestradiol by the ovary $[33,34]$.

The action of IGF-I in the follicle is to stimulate follicle proliferation and steroidogenesis. When blood IGF-I concentrations are low such as, during negative energy balance, folliculogenesis and steroid secretion are suppressed as seen in the post-partum cow $[11,12,35,36]$. However, when IGF-I concentrations are elevated, their action on the follicle must be controlled to prevent possible ovarian hyperstimulation [33]. Since the feedback loops that control hepatic IGF-I secretion do not include the ovary, the intra-follicular actions of IGF-I must be controlled locally. In this respect it is not surprising that the follicles of large mono-ovulatory mammals such as humans, sheep and cattle, do not produce significant amounts, if any, of intra-follicular IGF-I [36-41]. Follicular production of IGF-I appears to be limited to small mammals such as rodents and the like [42] with very short oestrous cycles where ovulation is frequent and folliculogenesis very rapid, or to large mammals with high ovulation rates, such as the pig $[43,44]$.

In sheep, we suggest that the effect of increased nutrition on the IGF system is to reduce the follicular actions of IGF-I through the intra-follicular actions of IGF-II and the insulin-like growth factor binding proteins (IGFBP) 2, 4 and 5 acting to control IGF-I bioavailability in the follicle. Both glucose infusion and lupin feeding increases the expression of IGFBP2 and inhibit the expression of IGFIR $[23,45]$. Both of these effects can help to reduce the bioavailability of IGF-I in the follicle.

\section{FEEDBACK EFFECTS}

The evidence pointing to the follicle as the primary site of action for the nutritional manipulation of folliculogenesis is steadily accumulating. As a result of this, there has been a tendency to discount the importance of gonadotrophins and negative feedback in the process [18]. We now realise that this was an over simplistic and probably incorrect interpretation of earlier data. The gonadotrophins, particularly FSH, and the negative feedback loops of the hypothalamo-pituitary-ovarian axis, are critically important in modulating follicular response to nutritional stimulation. In the ewe, ovulation can occur on either ovary and it appears to be a random process that is not influenced by the presence or absence of a corpus luteum [46]. Thus, a model of nutritional effects on folliculogenesis that proposes purely direct, local actions of nutrition on the follicle is not sustainable.

\subsection{Ovarian hormones}

Both the infusion of glucose and the feeding of a supplement of lupin grain suppress oestradiol secretion during the follicular phase of the oestrous cycle (Fig. 5) and this appears to be a direct effect on the follicle because it takes place in the presence of either unchanged or slightly increased concentrations of FSH. It is not clear if these effects of nutrition alter FSH-stimulated intracellular signalling pathways or FSH-stimulated aromatase activity per se.

The effect of nutrition on follicular inhibin secretion has not been studied and there are no published data on the subject. This is an important omission that should be addressed.

\subsection{Follicle stimulating hormone (FSH)}

The effects of nutrition on the blood concentrations of FSH are very problematic and no consistent picture has emerged 
despite a large number of published papers on the subject. There are a number of reasons for this lack of clarity. First, the effect of nutrition on FSH remains subject to negative feedback regulation and any nutritional stimulation of FSH concentrations would in theory, be quickly corrected by the negative feedback homeostasis. Second, we have no clear picture of the rapidity of negative feedback correction following nutritional stimulation of FSH. However, experiments using hemiovariectomy show that FSH concentrations double within $12 \mathrm{~h}$ of removal of one ovary and then return to baseline concentrations by $24 \mathrm{~h}$ ([33], A. Somchit et al. unpublished data). The effect of nutrition on FSH is likely to be rapid, transient and with a response in the normal range of blood concentrations. Bearing this in mind, it is not surprising that the effect of nutrition on FSH concentration remain unclear and difficult to demonstrate.

\section{FOLLICLE WAVES}

The normal follicle wave is the functional consequence of hypothalamopituitary-ovarian negative feedback. Waves last approximately 5 to 10 days and form in response to the combined effects of negative feedback by follicular hormones (oestradiol and inhibin) and the ovarian trophic effects of FSH. We suggest that, since the follicle wave and the nutritional influence on folliculogenesis both involve physiological perturbations of the negative feedback system that nutrition should also affect the duration of the follicle wave.

From a theoretical view the effect of nutrition on the follicle wave would be to lengthen it because nutritional supplementation would suppress oestradiol secretion from the dominant follicle allowing the dominant follicle to maintain its dominance for a longer time. There is some evidence for this in sheep $[47,48]$ and cat- tle [47]. In these experiments, the effect of nutrition was to either shorten the length of the follicle wave with under-nutrition [49] or to lengthen the follicle wave with supplementary nutrition $[18,47]$.

\subsection{Follicle waves (non-ovulatory) during the luteal phase}

The effect of supplementary nutrition on the non-ovulatory follicle wave in the luteal phase of the cycle is likely to be minor and within the normal physiological variation in FSH concentrations over a follicle wave. This is because of the effects of luteal progesterone on LH pulsatility that limit follicular oestradiol secretion and mask any potential nutritional effect. Furthermore, since non-ovulatory follicle waves are not well synchronised between ewes within a flock; any effect will be averaged among ewes and will be hidden in the normal variation in FSH concentrations at different stages of a follicle wave.

\subsection{Ovulatory follicle waves}

The effect of nutrition on the ovulatory wave is likely to be more evident because the progesterone brake on LH pulsatility and follicular oestradiol secretion is removed by luteolysis. Thus the expected follicular phase increase in oestradiol is attenuated by nutritional inhibition and consequently the normal follicular phase decline of FSH delayed because of reduced negative feedback. This would allow additional follicles to survive and the ovulation rate to increase. A delay in FSH suppression of about 8 to $12 \mathrm{~h}$ has been observed in ewes infused with glucose [21] and in ewes fed a lupin grain supplement [20]. Although these ideas about the relationship between nutritional stimulation and the follicle wave are supported by some data, they are speculative and a promising field for future investigation. 


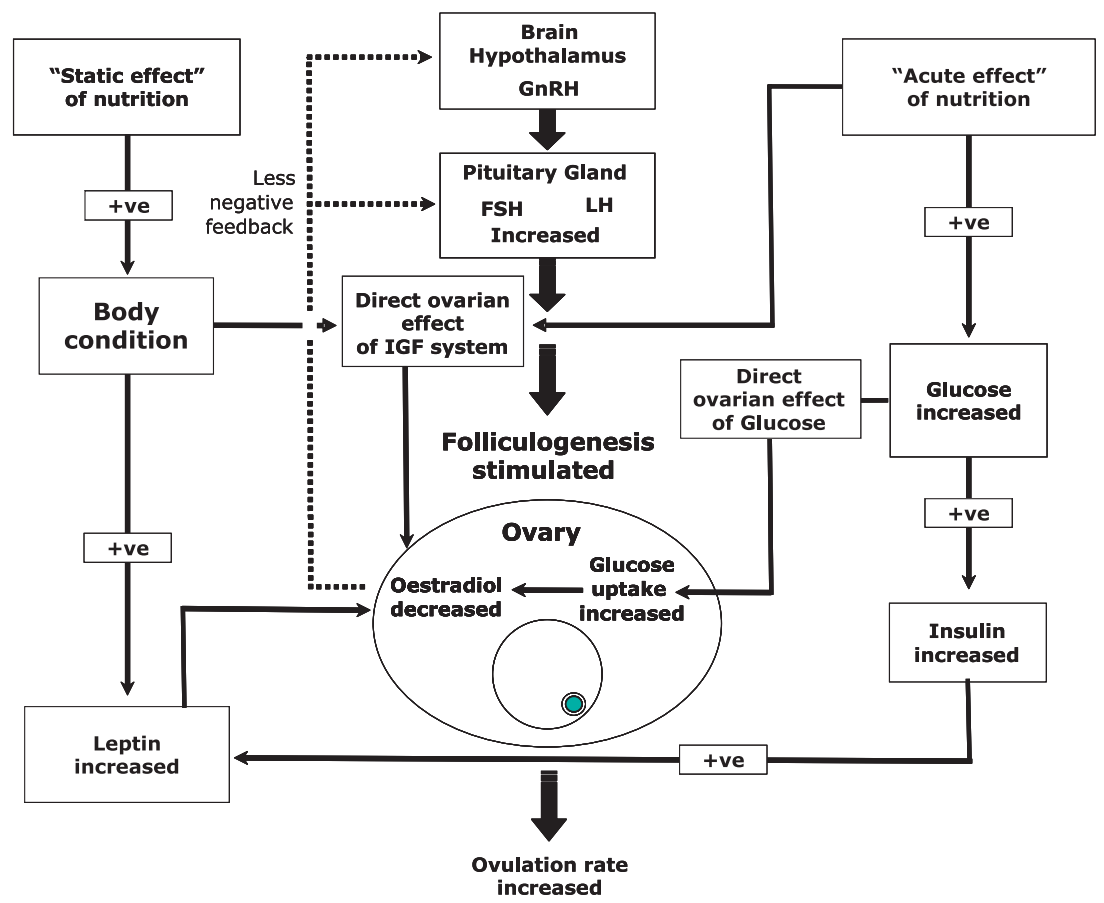

Figure 6. A model for the nutritional regulation of folliculogenesis and ovulation rate in the ewe (see text for explanation).

\section{A SYNTHESIS OF MECHANISMS}

Recent advances in our knowledge about the nutritional regulation of folliculogenesis and ovulation rate in the ewe have advanced the subject to the point at which testable, mechanistic models can be proposed. One such model is shown in Figure 6 . The model proposes that the main action of nutrition on the ovary is a direct inhibition of follicular oestradiol secretion by at least 3 metabolic systems and we now have strong in vivo evidence to support this claim ([28,29], J.A. Downing and R.J. Scaramuzzi, unpublished data - see Fig. 5). The metabolic modulatory systems are insulin-glucose, leptin and IGF. We suggest that, all three metabolic modulatory systems appear to have intra-follicular actions in the "acute" effect of nutrition, whereas with the "static" and "dynamic" effects modulation is mediated principally, by the leptin system. However, it is not possible to definitively exclude either the insulin-glucose or the IGF systems from the mechanism of the "static" and "dynamic" effects. The precise intra-follicular and intracellular mechanisms of these effects are as yet unclear but what is clear is that all 3 systems are involved and that there are complex interactions among these systems in mediating follicular responses to nutrition.

The nutritional suppression of oestradiol secretion leads to compensatory increases in FSH secretion that stimulate folliculogenesis and restores negative feedback homeostasis. Nutrition-induced changes in FSH secretion are indirect and in response to suppressed oestradiol secretion. They are also rapid, transient and therefore difficult to observe, but they are 
present and they can be observed using appropriate experimental models $[20,21,23]$.

\section{CONCLUSIONS}

This paper presents a model for nutritional influences on folliculogenesis and ovulation rate in sheep and the results of selected experiments from our group that lend support to the model. We believe that this model is a sound base from which to advance our understanding of the actual mechanisms that underlie this phenomenon and to then apply this understanding in commercial animal production systems.

In the future, large-scale commercial animal production, if it is to survive, will have to meet consumer demands for high quality animal products produced in systems that are socially acceptable and economically viable. A more complete understanding of how and when nutrition affects ovulation rate will facilitate the application of targeted nutrition in sheep production systems to optimise reproduction. Targeted nutrition that meets the "clean, green and ethical" standards has been pioneered in Australia by Graeme Martin [7] and may provide an alternative approach to managing reproduction in commercial systems that do not depend on the use of exogenous hormones.

\section{ACKNOWLEDGEMENTS}

The authors wish to thank Professor GB Martin for his constructive comments on the manuscript.

\section{REFERENCES}

[1] Lindsay DR, Martin GB, Williams IH. Nutrition and reproduction. In: King GJ (Ed), Reproduction in Domesticated Animals: World Animal Science Series Elsevier Science Publishers, Amsterdam, Holland, 1991, p 459-491.
[2] Lucy MC. Mechanisms linking nutrition and reproduction in postpartum cows. Reproduction Suppl 2003, 61: 415-427.

[3] I'Anson H, Foster DL, Foxcroft GR, Booth PJ. Nutrition and reproduction. Oxf Rev Reprod Biol 1991, 13: 239-311.

[4] Cox NM. Control of follicular development and ovulation rate in pigs. J Reprod Fertil Suppl 1997, 52: 31-46.

[5] Hazeleger W, Soede N, B Kemp B. The effect of feeding strategy during the prefollicular phase on subsequent follicular development in the pig. Domest Anim Endocrinol 2005, 29: 362-370.

[6] Sharpe RM, Franks S. Environment, lifestyle and infertility-an inter-generational issue. Nat Cell Biol 2002, Suppl 4: s33-s40.

[7] Martin GB, Milton JTB, Davidson RH, Banchero Hunzicker GE, Lindsay DR, Blache D. Natural methods for increasing reproductive efficiency in small ruminants. Anim Reprod Sci 2004, 82-83: 231-245.

[8] Wade GN, Jones JE. Neuroendocrinology of nutritional infertility. Am J Physiol Regul Integr Comp Physiol 2005, 287: R1277R1296.

[9] Lozana JM, Lonergran P, Boland MP, O'Callaghan D. Influence of nutrition on the effectiveness of superovulation programmes in ewes: effect on oocyte quality and postfertilization development. Reproduction 2003, 125: 543-553.

[10] Kiyma Z, Alexander BM, Van Kirk EA, Murdoch WJ, Hallford DM, Moss GE. Effects of feed restriction on reproductive and metabolic hormones in ewes. J Anim Sci 2004, 82: 2548-2557.

[11] Gong JG. Influence of metabolic hormones and nutrition on ovarian follicle development in cattle: practical implications. Domest Anim Endocrinol 2002, 23: 229-241.

[12] Wathes DC, Taylor VJ, Cheng Z, Mann GE. Follicle growth, corpus luteum function and their effects on embryo development in postpartum dairy cows. Reproduction Suppl 2003, 61: 219-237.

[13] Parr RA, Davis IF, Fairclough RJ, Miles MA. Overfeeding during early pregnancy reduces peripheral progesterone concentration and pregnancy rate in sheep. J Reprod Fertil 1987, 80: 317-320.

[14] Parr RA, Davis IF, Miles MA, Squires TJ. Feed intake affects metabolic clearance rate of progesterone in sheep. Res Vet Sci 1993, 55: $306-310$. 
[15] Oldham CM, Lindsay DR. Laparoscopy in the ewe: A photographic record of the ovarian activity of ewes experiencing normal or abnormal oestrous cycles. Anim Reprod Sci 1980, 3: 119-124.

[16] Knight TW, Oldham CM, Lindsay DR Studies in ovine infertility in agricultural regions in Western Australia: The influence of a supplement of lupins (Lupinus angustifolius cv. Uniwhite) at joining on the reproductive performance in ewes. Austral J Agricul Res 1975, 26: 567-575.

[17] Downing JA, Scaramuzzi RJ. Nutrient effects on ovulation rate, ovarian function and the secretion of gonadotrophic and metabolic hormones in sheep. J Reprod Fertil Suppl 1991, 43: 209-227.

[18] Scaramuzzi RJ, Campbell BK. Physiological regulation of ovulation rate in the ewe: A new look at an old problem. In: Oldham CM, Martin GB (Eds), and IW Purvis School of Agriculture (Animal Science), Reproductive Physiology of Merino Sheep - Concepts and Consequences. The University of Western Australia, Perth, Australia, 1990, p 71-84.

[19] Scaramuzzi RJ, Adams NR, Baird DT, Campbell BK, Downing JA, Findlay JK, Henderson KM, Martin GB, McNatty KP, McNeilly AS, Tsonis CG. A model for follicles selection and the determination of ovulation rate in the ewe. Reprod Fertil Dev 1993, 5: 459-478.

[20] Muñoz-Gutiérrez M, Blache D, Martin GB, Scaramuzzi RJ. Folliculogenesis and ovarian expression of mRNA encoding aromatase in anoestrous sheep after 5 days of glucose or glucosamine infusion or supplementary lupin feeding. Reproduction 2002, 124: 721731.

[21] Downing JA, Joss J, Scaramuzzi RJ. Ovulation rate and the concentrations of gonadotrophins and metabolic hormones in ewes infused with glucose during the late luteal phase of the oestrous cycle. J Endocrinol 1995, 146: 403-410.

[22] Blache D, Tellam RL, Chagas LM, Blackberry MA, Vercoe PE, Martin GB. Level of nutrition affects leptin concentrations in plasma and cerebrospinal fluid in sheep. J Endocrinol 2000, 165: 625-637.

[23] Muñoz-Gutiérrez M. The effect of glucose and leptin on folliculogenesis in the ewe. $\mathrm{PhD}$ thesis University of London, 2005.

[24] Downing JA, Joss J, Connell P, Scaramuzzi RJ. Ovulation rate and the concentration of gonadotrophic and metabolic hormones in ewes fed lupin grain. J Reprod Fertil 1995, 103: 137-145.

[25] Gong JG, Bramley TA, Webb R. The effect of recombinant bovine somatotrophin on ovarian follicular growth and development in heifers. J Reprod Fertil 1993, 97: 247-254.

[26] Gong JG, Baxter G, Bramley TA, Webb $R$. Enhancement of ovarian follicle development in heifers by treatment with recombinant bovine somatotrophin: a dose-response study. J Reprod Fertil 1997, 110: 91-97.

[27] Kendall NR, Scaramuzzi RJ, Baird DT, Campbell BK. Lupins modulate folliculogenesis directly by an FSH-independent mechanism. Reproduction 2003, Abstract Series 30: 29.

[28] Muñoz-Gutiérrez M, Finlay P, Adam CL, Wax G, Campbell BK, Kendall NR, Khalid M, Forsberg M, Scaramuzzi RJ. The effect of leptin on folliculogenesis and the follicular expression of mRNA encoding aromatase, IGF-IR, IGFBP-2, IGFBP-4, IGFBP-5, leptin receptor and leptin in ewes. Reproduction 2005, 130: 869-881.

[29] Kendall NR, Scaramuzzi RJ, Baird DT, Webb R, Campbell BK. Direct in vivo effects of leptin on ovarian steroidogenesis in sheep. Reproduction 2004, 128: 757-765.

[30] Williams SA, Blache D, Martin GB, Scaramuzzi RJ. The effect of oral administration of a glucogenic mixture on ovulation rate and characterisation of GLUT1 and GLUT4 in sheep ovarian follicles. J Reprod Fertil 2001, 122: 947-956.

[31] Scaramuzzi RJ, Campbell BK, Souza CJH, Baird DT. Glucose uptake and lactate production by the autotransplanted ovary during the luteal and follicular phases of the oestrous cycle. In: Proceedings of the 6th International Symposium on Reproduction in Domestic Ruminants 2002, Abstract A70.

[32] Leury BJ, Murray PJ, Rowe JB. Effect of nutrition on the response in ovulation rate in Merino ewes following short-term lupin supplementation and insulin administration. Austral J Agricul Res 1990, 41: 751-759.

[33] Campbell BK. Factors affecting ovulation rate in sheep and cattle. $\mathrm{PhD}$ thesis University of Sydney, 1988.

[34] Scaramuzzi RJ, Murray JF, Downing JA, Campbell BK. The effects exogenous growth hormone on follicular steroid secretion and ovulation rate in sheep. Domest Anim Endocrinol 1999, 17: 269-277.

[35] Beam SW, Butler WR. Effects of energy balance on follicular development and 
first ovulation in postpartum dairy cows. J Reprod Fertil Suppl 1999, 54: 411-424.

[36] Bondy CA, Chin E, Zhou J. Significant species differences in local IGF-I -II gene expression. Adv Exp Med Biol 1993, 343: 73-77.

[37] Perks CM, Denning-Kendall PA, Gilmour RS, Wathes DC. Localization of messenger ribonucleic acids for insulin-like growth factor I (IGF-I), IGF-II, and the type 1 IGF receptor in the ovine ovary throughout the estrous cycle. Endocrinology 1995, 136: 52665273.

[38] Perks CM, Peters AR, Wathes DC. Follicular and luteal expression of insulin-like growth factors I and II and the type 1 IGF receptor in the bovine ovary. J Reprod Fertil 1999, 116: 157-165.

[39] Mazerbourg S, Bondy CA, Zhou J, Monget P. The insulin-like growth factor system: a key determinant role in the growth and selection of ovarian follicles? a comparative species study. Reprod Domest Anim 2003, 38: 247-258.

[40] Hastie PM, Haresign W. Expression of mRNAs encoding insulin-like growth factor (IGF) ligands, IGF receptors and IGF binding proteins during follicular growth and atresia in the ovine ovary throughout the oestrous cycle. Anim Reprod Sci 2006, 92: 284-299.

[41] Leeuwenberg BR, Hurst PR, McNatty KP. Expression of IGF-I mRNA in the ovine ovary. J Mol Endocrinol 1995, 15: 251-258.

[42] Hernandez ER. Regulation of the genes for insulin-like growth factor (IGF) I and II and their receptors by steroids and gonadotropins in the ovary. J Steroid Biochem Mol Biol 1995, 53: 219-221.
[43] Samaras SE, Guthrie HD, Barber JA, Hammond JM. Expression of the mRNAs for the insulin-like growth factors and their binding proteins during development of porcine ovarian follicles. Endocrinology 1993, 133: 2395-2398.

[44] Zhou J, Adesanya OO, Vatzias G, Hammond JM, Bondy CA. Selective expression of insulin-like growth factor system components during porcine ovary follicular selection. Endocrinology 1996, 137: 4893-4901.

[45] Muñoz-Gutiérrez M, Blache D, Martin GB, Scaramuzzi RJ. Ovarian follicular expression of mRNA encoding the type I insulin like growth factor receptor (IGF-IR) and insulin like growth factor binding protein 2 (IGFBP2) in anoestrous sheep after 5 days of glucose or glucosamine or supplementary feeding with lupin grain. Reproduction 2004, 128: $1-11$.

[46] Scaramuzzi RJ, Downing JA. The distribution of ovulations from the ovaries of Merino and Border Leicester $\times$ Merino ewes and its effect on the survival of their embryos. Anim Reprod Sci 1997, 47: 327-336.

[47] Viñoles C, Forsberg M, Martin GB, Cajarville C, Repetto J, Meikle A. Shortterm nutritional supplementation of ewes in low body condition affects follicle development due to an increase in glucose and metabolic hormones. Reproduction 2005, 129: 299-309.

[48] Viñoles GC. Effect of nutrition on follicle development and ovulation rate in the ewe. PhD thesis Swedish University of Agricultural Sciences, 2003.

[49] Murphy MG, Enright WJ, Crowe MA, McConnell K, Spicer LJ, Boland MP, Roche JF. Effect of dietary intake on pattern of growth of dominant follicles during the oestrous cycle in beef heifers. J Reprod Fertil 1991, 92: 333-338.

To access this journal online: www.edpsciences.org 